DOI https://doi.org/10.36059/978-966-397-194-0/196-211

\title{
THE METHODS OF WORKING WITH THEMATIC TEXTS IN ESP CLASSES
}

\section{Svitlana Chernyshova}

\section{INTRODUCTION}

The globalization and digitization of society in the $21^{\text {st }}$ century require a radical revision of all areas of human activity, mainly the educational system and teaching. Ukrainian expert in English language studies, Professor of Uzhhorod University Myroslava Fabian in her recent research provides an important thesis that reveals the stress points of the contemporary communication and learning studies talking into account the importance of communicative paradigm in which we exist:

Nowadays the world is based on communication which presupposes the process of sharing meaning through verbal and nonverbal behaviour. In our time of globalization, we have more to be exposed to and share with than ever before in terms of culture - beliefs, worldviews, values, attitudes and ideologies - but at the same time much of them remains different and unshared, which is enhanced by raising people's awareness of cultural, ethnic, and religious identities. The Internet and modem technology have opened up new marketplaces, and allow us to promote our businesses to new geographic locations and cultures. Today, we communicate beyond the national borders by emailing, chatting, blogging, web browsing besides speaking and writing. In these days of global networking, we are thrown into the society of hybrid, changing and conflicting cultures, where we are expected to become pluricultural individuals. In the light of cross-cultural communication, the language policy and planning of the Council of Europe is a grand experiment based on plurilingualism and pluriculturalism.

Effective communication with people of different cultures is especially challenging. Cultures provide people with ways of thinking ways of seeing, hearing, and interpreting the world. Moreover, the same words can mean different things to people from different cultures, even when they talk the "same" language. When the languages are different, 
and translation has to be used to communicate, the potential for misunderstandings increases ${ }^{1}$.

The world has changed - students have changed and teachers have to change as well. Most modern students from around the world are the representatives of generation $Z$ by their age, according to 'The Theory of Generations' developed by American researchers William Strauss and Neil Howe. Generation Z refers to the children born after 1995 in digital reality. The ability to "see" multiple screens simultaneously generates the ability to perceive information quickly and to process it instantaneously. Therefore, traditional forms and methods of teaching aimed at gaining knowledge by presenting information by the teacher and passive memorizing it by the student are not effective today.

The Ukrainian scholar Iryna Andrusiak argues that

In foreign language teaching, a search for the most effective way is one of the tasks applied linguists has been trying to fulfill over a century. There has been a lot of debate and discussion about the centrality of grammar and vocabulary in the language curriculum, the importance of accuracy and fluency in the learners' language development, effective methods, approaches and learning strategies of EFL teaching. Although much has been done to solve the most debatable problems, the teaching profession is continually exploring new ways of addressing teaching and learning options to establish more effective teaching and learning practices. Alongside the total physical response, the silent way, suggestopedia, community language learning, multiple intelligences, etc., the lexical approach is referred to a set of alternative approaches and methods in language teaching which are hardly ever addressed by national EFL curricula. Therefore, the research focusing on the methodological foundations underlying the lexical approach and its pedagogical implications for EFL teaching proves to be highly topical. It is commonly accepted that vocabulary as well as grammar are central to language acquisition. However, in contrast to grammar, vocabulary teaching in EFL school classrooms does not prove to be effective. The degree to which vocabulary should be taught, corrected and worked on and methods which should be employed are widely disputed in teaching industry. Recently, vocabulary teaching focus has been shifted to teaching more or less fixed strings of words in contrast to word lists. The latter has been the most

${ }^{1}$ Fabian M. (2019). Interdisciplinary approach to cross-language and crosscultural communication studies. http://respacoll.uzhnu.edu.ua/article/view/187079/ 186480 (accessed 12 January 2020), p. 10. 
popular strategy that both teachers and learners employ throughout a great many years ${ }^{2}$.

It should be noted that on December 4, 2019, the Ukrainian-British Forum "Excellence in Teaching and Learning in Higher Education" was held in Ukraine, which became the first event in a series of activities in a three-year program aimed at improving the quality of teaching in higher education in Ukraine. The key issues of the forum were teaching excellence as a priority for the development of the European Higher Education Area; professional development of university teachers in Ukraine: status and needs; presentation of the UK experience on improving teaching at universities; presentation of the experience of Ukrainian universities on the professional development of teachers, etc. ${ }^{3}$

Professor Myroslava Fabian underlines the idea the these days

Learning as well as teaching a foreign language implies some degree of becoming aware of a foreign culture, and it is important to understand what we mean by the process of cultural learning. Many students in foreign language classrooms learn the language with little or no sense of the depth of cultural norms and patterns of the people who speak the language. Culture learning is a process of creating shared meaning between cultural representatives. It is experiential, a process that continues over years of language learning, and penetrates deeply into one's patterns of thinking, feeling, and acting. Moreover, the second language learning involves the acquisition of a second identity. This creation of a new identity is at the heart of culture learning, or what some might call acculturation. By culture a shared background (for instance, national, ethnic, religious) resulting from a common language and communication style, customs, beliefs, attitudes and values is meant ${ }^{4}$.

Since any English for Specific Purposes (ESP) course is based on the major-specific discipline, a thematic text is a high-quality and reliable cognitive material that complements the knowledge acquired in the course of the study and ensures that the prospective specialist has a decent

${ }^{2}$ Andrusiak I. (2019). The lexical approach to EFL teaching: methodological foundations and pedagogical implications http://respacoll.uzhnu.edu.ua/article/view/ 188462/187839 (accessed 12 January 2020), pp. 282-283.

http://www.britishcouncil.org.ua/programmes/education/higher-educationemployability/teaching-excellence-forum

${ }^{4}$ Fabian M. (2019). Interdisciplinary approach to cross-language and crosscultural communication studies. http://respacoll.uzhnu.edu.ua/article/view/187079/ 186480 (accessed 12 January 2020), p. 11. 
command of the English language. The selection of educational material follows the provisions of the Common European Framework of Reference for Languages, which states that the basic principles of the selection of language-teaching tools provide for the selection of original texts, taking into account the professional needs of those studying a foreign language [1: 81]. Hence, a thematic text is the main means of learning ESP; a source of thematic vocabulary; and a way of shaping the linguistic, professional and sociocultural competence of students by virtue of 'overlaying' foreign language skills on the substantive content of the profession while performing professional $\operatorname{tasks}^{6}$ [5: 199]. The lexical, grammatical and semantic fabric of the text forms an understanding and sense of the language, developing linguistic and cognitive skills.

Iryna Andrusiak draw's scholars' attention to S. Lindstromberg's theory. The researcher

presents a commonly held view of language competence with regard to both output and input in the following way:

- In speaking and writing:

intended meanings $\Rightarrow$ words + grammar / morphology $\Rightarrow$ meaningful output

- In listening and reading:

input $=>$ grammar + words $=>$ understood meanings $<\ldots>$.

Before the advent of the lexical approach, the popular belief was that a moderately substantial knowledge of grammar and a few thousand words are needed for effective communication. The belief was based on the view on our language ability according to which people have an outstanding ability to combine single words into bigger strings of words in no time to produce meaningful output and to analyse the input by parsing and understanding strings of words. Applying computer metaphor makes the description of our language ability even clearer: human memories are relatively small in a sense that they retain only a few thousand words and grammar rules to apply to them; but human on-line processors are very powerful since they perform combining and parsing operations with single words at lightning speed. Accordingly, in order to

5 Zahalnoieevropeiski rekomendatsii z movnoi osvity: vyvchennia, vykladannia, otsiniuvannia (2003). Nauk. red. ukrainskoho vydannia S. Yu. Nikolaieva. - K. : Lenvit, 2003, p. 81.

6 Sekret I. V. (2010). Model formuvannia inshomovnoi profesiinoi kompetentnosti $\mathrm{v}$ umovakh dystanciynoi osvity. Visnyk LNU imeni Tarasa Shevchenka. № 17 (204). P. 199. 
empower learners' online-processors a wealth of time was spent on grammar" ${ }^{\prime 7}$.

Reading texts in English is one of the ways of learning the English language. Well-selected English texts significantly contribute not only to the enhancement of the linguistic competence but also to the motivation for the student to work independently. Reading texts can differ in terms of both their purposes and the ways in which such purposes are attained. The most common ones include replenishing general or thematic vocabulary; improving the pronunciation of English words and phrases; and revising the rules of English grammar through the analysis of typical examples available in the text. Attaining those purposes obviously requires selecting relevant English texts.

It should be noted that today we need to analyze new methodological approach of teaching English as a foreign language.

As M. Fabian states,

A methodology for investigating how an individual uses language and other semiotic activity to create and use new models of conduct and how this varies from the cultural norm should be incorporated into the study of language socialization. The study of languages other than one's own can serve not only to help one realize what we as humans have in common, but also to assist in the understanding of the diversity which underlines our languages' methods of constructing and organizing knowledge. Such understanding has profound implications with respect to developing a critical awareness of social relationships. Understanding of the latter and the way other cultures work is the groundwork of successful globalization processes functioning ${ }^{8}$.

In terms of their thematic orientation, texts can be characterised by a large variety of grammatical forms and lexical material. The teacher can determine more accurately the students' knowledge of the foreign language and, accordingly, pick up the texts suitable for their level. Texts in English can be taken from specialised journals and newspapers or works written by experts in the field in question. Since student experience certain difficulties in processing a thematic text-due to their lack of

${ }^{7}$ Andrusiak I. (2019). The lexical approach to EFL teaching: methodological foundations and pedagogical implications http://respacoll.uzhnu.edu.ua/article/view/ 188462/187839 (accessed 12 January 2020), p. 286

${ }^{8}$ Fabian M. (2019). Interdisciplinary approach to cross-language and crosscultural communication studies. http://respacoll.uzhnu.edu.ua/article/view/ 187079/186480 (accessed 12 January 2020), p. 12. 
linguistic and professional competence - the teacher must carefully plan the work with the text, identify potentially problematic parts, prepare methods for processing their basic lexical and grammatical features, and come up with a set of relevant exercises. Traditionally, working with the text includes three stages, namely pre-textual, textual, and post-textual ${ }^{9}$ $[2 ; 4]$.

Let us consider the work with a thematic text by the example of $O n$ the Uses of Philosophy by Will Durant ${ }^{10}$ [7], intended for students of philosophy. There, the following stages can be identified:

\section{Working with active vocabulary included in the text}

Compiling a thematic dictionary to the text and working with this dictionary is one of the types of pre-text exercises that enable students to understand the main idea of the text and, subsequently, become the basis for understanding and acquiring new material. A thematic dictionary offers the lexical minimum, which makes it possible for students to speak on the given topic by providing the precise expression of thoughts and correct word usage. The lexical minimum can be used by students to read a thematic text with the accompanying task of studying the words and phrases on the given topic, finding in the text sentences with those words and phrases, and translating them, for example existence, meaningless, delight, incomparably, wistful, vacillation and futility, chaos, decipher, maelstrom, circumstance, inevitable, the creation of death.

In studying new words and phrases, it is necessary to follow a three-point plan: (a) finding out the meaning(s) of unfamiliar words and/or phrases, (b) writing them down and (c) learning the words and phrases by repetition. The first point (finding the meaning(s)) should not take up too much time if the following recommendations are applied: a word or phrase first has to be understood from its context, found in a bilingual dictionary or, should a student's vocabulary be sufficient, found in a monolingual dictionary. The general rule is to read the text carefully, clarifying the meaning(s) of each unfamiliar word or phrase.

Of particular interest at the pre-textual stage is the study of idiomatic expressions or phrasal verbs. In the first instance, it should be

${ }^{9}$ Kalinina L., Samoiliukevych I., Anderson K. (2001). Getting America-Wise through reading. Navchalnyi posibnyk $z$ anhliiskoi movy dlia studentiv vyshchhykh navchalnykh zakladiv. U 2-kh kn. Kyiv: Ped. dumka. Kn. 1, p. 4.

${ }^{10}$ The Story of Philosophy: navch. posibnyk z anhliyskoi movy (2017). Eds. S. O. Chernyshova, O. P. Tokmenko. Kyiv: VPTs "Kyivskyi universytet”, 142 p. 
explained to students that they are rarely to be used in formal writing and are more attributable to colloquial speech or belle-lettres. Since such expressions and phrases do not directly correspond with lexical units in students' native language, they deserve special attention and care. The teacher may need to use additional materials in order to help students use idiomatic expressions correctly in their speech.

It is therefore advisable that a separate set of exercises be prepared for learning idioms and phrasal verbs, such as inserting prepositions and/or adverbs; finding synonyms for highlighted parts of the text from among given idioms and/or phrasal verbs; filling in gaps with correct phrasal verbs; etc.

\section{Working with a thematic descriptive text}

After initial difficulties in comprehending the text have been dealt with, students move on to reading the given thematic text. Working with such texts pursues the aim of developing students' reading, pronunciation and translation skills. At this stage, students are asked to read and translate the text.

After reading the text, students do lexical exercises with a view to revising and checking their understanding of the text. Of particular importance are lexical exercises that contribute to developing the ability of determining the meaning of a given word or phrase in a particular context; determining the role of words in the lexical system of language; and analysing the meaning of a keyword (or keywords) in a particular context. The exercises recommended after reading the text should be designed in a way so that students will use the words and/or phrases selected at the previous stage for translating, retelling, and discussing the text, both orally and in writing. Such exercises often include the task of writing down keywords from the given text; answering questions based upon the text; or making up a plan of the text with the help of new vocabulary.

\section{Doing post-text exercises for revising the lexical minimum of the lesson, including translating English words and/or phrases into Ukrainian}

This stage helps students compare lexical units of different languages and ascertain their meaning. Such post-text exercises may include choosing a keyword or keywords from the given text and/or making up sentences with one and/or more keywords. 
To take an example, the following is an exercise that checks students' ability to make up correct sentences and use new vocabulary in correct contexts:

Make up sentences using the following words:

A pleasure, the Mirages, There, and, a lure, in, of, even, metaphysics, is, philosophy, in.

Another example illustrates how exercises can be used to both check students' comprehension of the given text and understanding of new vocabulary:

\section{Detect the right statement:} interpretation.

- Science is an analytical description; philosophy is emotional

- The scientist is as interested in the leg of a blessing as in the creative throes of a genius.

- Philosophy seems to stand still, perplexed; but only because she leaves no fruits of victory to her daughters the sciences.

- Philosophy accepts the hard and hazardous task of dealing with problems not yet open to the methods of science-problems like good and evil, beauty and ugliness, order and freedom, life and death.

Some exercises require selectively learning the given text's context. They include the fill-in-the-gaps type of exercises, such as the following one:

\section{Complete the following sentences:}

But the philosopher is not content to describe the fact; he wishes to 1) its relation to experience in general, and thus to get its meaning and worth; he combines things in 2) ; he tries to put it together better than before, that 3) which the inquisitive scientist has analytically taken apart.

It should be noted, however, that plainly taking parts of the given text for such exercises should be avoided. The teacher is to paraphrase parts of the text so that such exercises should be effective. In addition, if options are provided for each gap in such exercises and students are asked to choose the correct option, the teacher may ask them to explain why they have chosen this option over the others. Let us take the sentence from the above exercise to illustrate the point:

But the philosopher is not content to describe the fact; he wishes to 1) its relation to experience in general, and thus to get its meaning and worth...
A. purify
B. ascertain
C. locate
D. expand 
There, students must explain why option B is the only correct one, drawing upon the lexical and grammatical contexts of the sentence, i.e. option A ("purify") cannot be lexically used with "relation", etc.

Another effective type of exercises checking the understanding of the given text involves identifying redundant words, such as:

Read the text below and decide which lines of the text contain unnecessary words.

\begin{tabular}{|l|l|c|}
\hline$\#$ & \multicolumn{1}{|c|}{ Line } & Tick \\
\hline 1 & $\begin{array}{l}\text { In every field of activity there is a philosophy of it that } \\
\text { involves in }\end{array}$ & \\
\hline 2 & $\begin{array}{l}\text { questioning of its fundamental concepts, principles, } \\
\text { and methods. }\end{array}$ & \\
\hline 3 & $\begin{array}{l}\text { So, there is philosophy of science, philosophy of } \\
\text { religion, philosophy of }\end{array}$ & \\
\hline 4 & $\begin{array}{l}\text { art, and so on. Nearly always, some of the best } \\
\text { between practitioners in }\end{array}$ & \\
\hline 5 & each field are interested in its philosophy. & \\
\hline
\end{tabular}

The system of recommended exercises may also include those aimed at explaining the meaning of some phrases from the text, as is shown by the following example:

Define the meaning of the phrase:

"To be a philosopher," said Thoreau, "is not merely to have subtle thoughts, nor even to find a school, but to love wisdom as it is to live, according to its dictates, a life of simplicity, independence, magnanimity, and trust."

With this type of exercises, a post-text discussion can be organised, where students express their ideas as to certain parts of the given text.

The above types of exercises can be used to check students' work on the adequate understanding of new vocabulary and the text in question, and to contribute to the active acquisition of new lexical material. They can be done and, consequently, checked both orally and in writing, taking little to no time during the lesson, which allows the teacher to effectively use the lesson time devoted to working with the thematic text.

It should be noted that, at this stage of working with a thematic text, the student is able to come up with a cohesive statement based upon the material of the text. Exercises of this type may include answering questions not directly related to the given text but based upon it, with arguments provided in favour of the answer given. This is the 
communicational method of checking not only a deeper understanding of the text, but also the student's ability to formulate clear statements on a specific topic in a particular context. On a more general level, in answering a question, students learn to choose from the text relevant vocabulary and link it to the situation in which it can be used; transform the linguistic material being studied; and use lexical units in various forms. Asking students to provide argument in favour of their opinion helps engage them in speech-related activities at different levels of language competence. These are open-ended exercises, i.e. tasks that do not have one correct answer and allow students to deal with them whatever their language proficiency is. The type of exercises in question can be formulated as follows:

\section{text? \\ Skim the text quickly and write down what you can remember., etc. \\ Such exercises allow each student to give answers of the complexity and length that that they are able to. Even an unprepared student can express his or her own point of view by doing them. This incentivises each student to participate in classwork, and develops their overall language skills. At the last stage of working with text, the teacher may give students the task of finding additional information or discussing the ideas formulated in the text.}

Can you add some more of your own to the information of the

\section{Innovative technologies in teaching English}

The priority approach in contemporary pedagogies today is the learning-by-doing approach based on a student-centered model. This model involves active and engaged learners; independent, cooperative, collaborative, competitive learning (self, peer, groups), as well as studentled experiment and discovery. Innovative teaching technologies, active and interactive learning models are practice-oriented and require students' maximum activity and initiative, when they acquire knowledge on their own and the teacher only assists, directs and coordinates, i.e. the teacher becomes a professional facilitator who skillfully adjusts students' activity.

In our opinion, the most effective innovative learning technologies are the following forms and techniques:

- flipped classroom (the change in the way of presenting information; a flip between classwork and homework);

- double-flipped classroom (a role reversal between a student and a teacher); 
- gamification;

- project-based learning;

- case study;

- IT (digital / online / audio-visual resources);

- work in micro groups, teamwork that creates healthy competition, etc.

The increasing use of the practices of innovative technology in learning, teaching, research work and everyday life is crucial nowadays. The project-based learning (PBL) takes an important place among the innovative learning technologies. It is important, interesting and relevant for students because it demonstrates learning through practice, prepares future professionals to their professional activity and is the first attempt of professional self-realization.

We consider the "project" as a certain algorithm of actions, moderated by the teacher-facilitator and performed by students on their own, which is aimed at creating the final product. The results of the projects should be material, i.e. appropriately designed - video, PowerPoint presentation, poster as a consequence of practical research, development and design of the site, creation of digital stories, portfolios, photo collages, etc. It is designed to solve a problem, search for a common team solution and involves collaboration with peers. The purpose of the project is to create one's own product through cooperative activities.

While working on the project, students apply their knowledge and skills to solve realistic problems in the real world. Students acquire the experience of working in a team, negotiate, make common decisions and present the results of their activities together.

The project-based learning, as one of the innovative interactive learning technology, is gaining its popularity in the process of language (English) learning by the students of the National Aviation University (Kyiv, Ukraine). For instance, the third-year students majoring in "Journalism" ("Advertising and Public Relations") have created the project entitled "The Language of Newspapers" while studying "English for Specific Purposes", and the second-year students - the project entitled "The Language of Advertisement on the streets of Kyiv" during "English for Specific Purposes" course.

\section{Description of the projects \\ Project 1 \\ Project Title: "The Language of Newspapers"}


Type: practice-oriented linguistic project, aimed at developing students' language skills and skills necessary for future journalists.

Project participants: third-year-students majoring in "Journalism" (“Advertising and Public Relations") (24 students).

The final product of the project: The additional issue of "Aviator" newspaper (English version).

Topicality: A journalist has to develop the culture of speech and communication, as a literary language is the main tool of mass media. The ability to express the thoughts in writing, the ability to select the required information, and the development of skills to work in groups determine the relevance of this project. Working in a team with a set of responsibilities and tasks for each member encourages the student's autonomy and initiative. Students have to study the peculiarities of the journalistic style of English texts and compare them with Ukrainian ones, learn to write an article to a newspaper choosing the appropriate style, terminology, grammar forms and constructions

Purpose: to create a newspaper and develop the skills required for journalists in their future professional activity.

Tasks:

$\checkmark$ to analyze the writing style of American/British student newspapers;

$\checkmark \quad$ to define the journalism terms;

$\checkmark \quad$ to develop a set of skills necessary for future journalists: critical thinking and creativity (formulating ideas and solving problems), communication skills (writing and editing, making clear and well-written reports, explaining, articulating, presenting the material), organizational skills (setting and attaining goals, planning, meeting deadline); interpersonal skills (collaboration, working in a team to achieve a shared goal, assisting other team members), research skills (using various technological and information resources to collect information to create a new product);

$\checkmark$ to apply theoretical knowledge of language structure, spelling, punctuation, media techniques in practice while discussing and creating texts;

Duration: 3 months.

The plan of implementation:

$\checkmark$ preparation: students choose any British or American newspaper (e.g. Varsity (the newspaper of Cambridge University), The Harvard Crimson, etc) available online and make a thorough investigation into it for the content, style, terms, choice of grammar constructions and 
note their observations, present and discuss them in the classroom (webbased research, small groups discussions, class discussions);

$\checkmark$ students analyze the English version of 'Aviator' newspaper issued by the National Aviation University (Kyiv, Ukraine) both to detect any disadvantages in the content they would like to improve and identify any mistakes (e.g. inappropriate use of style, lexical and grammatical constructions);

$\checkmark$ setting the goal of creating the issue of 'Aviator' newspaper about the main events taking place at the National Aviation University, achievements and other topics of interest when students propose their ideas for content, pages, sections, columns, etc (brainstorming, class discussion);

$\checkmark$ students are divided into groups of five according to the newspaper section they have chosen, collect the material for this section, take interviews to prepare an article or articles for the newspaper (one page or section for each group);

$\checkmark$ each group of students proofreads the articles for errors and check the style, edits it for content and clarity, gives an attention-grabbing headline for the article, discusses the pictures or photos, etc;

$\checkmark$ students present the newspaper.

\section{Project 2}

Title: "The Language of Advertisement on the Streets of Kyiv"

Type (by method or type of activity dominating in the project): practice-oriented

Type (by content): linguistic, aimed at mastering the language material, developing certain language skills and skills of future copywriters, as well as studying linguistic features and linguistic realities.

Project participants: second-year-students majoring in "Journalism" ("Advertising and Public Relations") (26 students).

The final product of the project: PowerPoint presentation with the embedded video.

Topicality: the language of advertisement is an important tool for developing both the advertising industry and society as a whole, in which literacy is a factor in social success and one of the forces of professional growth. Nobody can be considered an educated person in the $21^{\text {st }}$ century without good communication skills (both oral and written, including correct speech). Therefore, a future copywriter has to develop the skill of critical attitude to advertising texts, revealing mistakes in them for creating their advertising texts in future professional activity. 
Purpose: to characterize and analyze the most frequent mistakes that occur in the advertisements on the streets of Kyiv, to develop recommendations for copywriters based on the analysis to enhance their culture of speech and avoid these mistakes in the future.

Tasks:

$\checkmark$ to identify the most common mistakes in the advertisements in Kyiv;

$\checkmark$ to organize the identified mistakes and classify them by presenting the results of the analysis in the form of diagrams;

$\checkmark$ to develop recommendations for enhancing the culture of speech for the authors of advertisements and to avoid similar linguistic mistakes in the future.

Duration: 2 months.

The plan of implementation: work;

- dividing students into micro groups, according to the type of

- collecting the material during the field research (mistakes in advertisements on the city streets);

- video recording to create a video clip;

- investigating the typology of mistakes and their systematization, in accordance with the violation of language standards;

- study of statistics (quantitative analysis of mistakes);

- creating a diagram based on the statistical analysis;

- creating the content of the text slides;

- video editing;

- creating a PowerPoint presentation.

\section{CONCLUSIONS}

The content derived from the given text and the system of relevant training exercises will form the basis for the development of competent dialogical and monological speech. Consequently, this leads to the next stage of working with the text, which involves processing information contained in the given text in order to formulate relevant, cohesive statements. The context of the text is used as the linguistic support for the development of students' linguistic skills as applicable in both oral and written speech. Formulating a statement based on the given text requires students to formulate the main idea of the text and select the relevant material from the text.

Therefore, lexical exercises formed on the basis of thematic texts are designed to develop students' lexical and linguistic competence. This 
allows students to correctly understand a foreign word; make conscious use of the structure of the meanings of foreign words; combine words and/or phrases in accordance with relevant lexical and grammatical rules; formulate and express an opinion in a foreign language in various form with thematic vocabulary; and finally, last but not least, understand thoughts expressed by other foreign-language speakers.

\section{SUMMARY}

In the paper, the author has provided guidelines on working with thematic texts with students of non-linguistic majors. It seeks to formulate effective and efficient methods of working with thematic texts, drawing upon the main types of working with texts in general. The article has made use of the method of analysing thematic texts and, therefore, argues that there are three basic steps in working with thematic texts, namely pretextual, textual, and post-textual. A set of exercises based on the book On the Uses of Philosophy by Will Durant has been used to illustrate the point. In the final analysis, the article argues that the methodology it sets out focuses on developing students' reading skills through helping them:

- correctly understand a foreign word;

- make conscious use of the structure of the meanings of foreign words;

- combine words and/or phrases in accordance with relevant lexical and grammatical rules;

- formulate and express an opinion in a foreign language in various form with thematic vocabulary;

- and understand thoughts expressed by other foreign-language speakers.

\section{REFERENCES}

1. Zahalnoieevropeiski rekomendatsii $\mathrm{z}$ movnoi osvity: vyvchennia, vykladannia, otsiniuvannia (2003). Nauk. red. ukrainskoho vydannia S. Yu. Nikolaieva. Kyiv: Lenvit, 2003, 273 p.

2. Kalinina L., Samoiliukevych I., Anderson K (2001). Getting America-Wise through reading. Navchalnyi posibnyk $z$ anhliiskoi movy dlia studentiv vyshchhykh navchalnykh zakladiv. U 2-kh kn. Kyiv: Ped. dumka. Kn. 1. 175 p.

3. Krat O. (2011). Komponenty systemy navchannia inozemnoi movy profesiynoho spriamuvannia cherez zmist profesiynoi diialnosti. Visnyk Dnipropetrovskoho universytetu imeni Alfreda Nobelia. № 2 (2). PP. 69-74. (Seriia "Pedahohika i psykholohiia"). 
4. Metodyka vykladannia inozemnykh mov $u$ serednikh navchalnykh zakladakh (2002). Pidruchnyk. Vyd. 2-e, vypr. i pererob; za red. S. Yu. Nikolaievoi. Kyiv: Lenvit. PP. 328-350.

5. Sekret I. V. (2010). Model formuvannia inshomovnoi profesiinoi kompetentnosti $\mathrm{v}$ umovakh dystanciynoi osvity. Visnyk LNU imeni Tarasa Shevchenka. № 17 (204). PP. 199-208.

6. Khrystova O. F. (2011). Vykorystannia fakhovykh tekstiv na zaniattiakh $\mathrm{z}$ angliyskoi movy za profesiynym spriamuvanniam / O. F. Khrystova // Naukovyi visnyk Melitopolskoho derzhavnoho pedahohichnoho universytetu imeni Bohdana Khmelnytskoho : zb. nauk. pr. № 6. PP. 220-225. (Seriia "Pedahohika").

7. The Story of Philosophy: navch. posibnyk z anhliyskoi movy (2017). Eds. S. O. Chernyshova, O. P. Tokmenko. Kyiv: VPTs "Kyivskyi universytet", $142 \mathrm{p}$.

\section{Information about the author: Svitlana Chernyshova,}

Ph.D., Assistant Professor of Institute of Philology, Taras Shevchenko National University of Kyiv 60, Volodymyrska str., Kyiv, 01033, Ukraine ORCID ID: orcid.org/0000-0003-0284-2001 